\title{
NEW DATA ON TWO SUBTERRANEAN SPECIES OF THE FAMILY NIPHARGIDAE FROM SPAIN, NIPHARGUS GALLICUS SCHELL., 1935 AND N. DELAMAREI RUFFO, 1954 (CONTRIBUTION TO THE KNOWLEDGE OF THE AMPHIPODA 282)
}

\author{
Gordan S. Karaman \\ Montenegrin Academy of Sciences and Arts, Podgorica, Montenegro \\ Corresponding author e-mail: karaman@t-com.me
}

New data of two poorly known subterranean species of the family Niphargidae (Amphipoda Gammaridea) from Spain are presented. Niphargus gallicus Schellenberg, 1935, known from southern France and Romania, is discovered in the subterranean waters of NE Spain and redescribed in detail. The variability of $N$. gallicus in Spain regarding the known taxonomical characteristics of this species from France and Romania is discussed. Niphargus delamarei Ruffo, 1954, was known from France and one locality in Spain, is discovered in wells of NE Spain, and often mixed with other Niphargus species. Some taxonomical characteristics and variability of this species are discussed.

Key words: taxonomy; Amphipoda; Niphargidae; Niphargus gallicus; N. delamarei; Spain

\section{INTRODUCTION}

The subterranean continental fauna of Amphipoda in Spain is only partially known, presented mainly by the taxa of the family Niphargidae ( $\mathrm{Ni}$ phargus Schiödte, 1849) and Haploginglymus Mateus \& Mateus, 1958) (Balazuc, 1957; Margalef, 1970; Morand-Chevat, 1972; G. Karaman, 1986) and genera of other families (Bogidiella Hertzog, 1933, Salentinella Ruffo, 1947, Pseudoniphargus Chevreux, 1901, Parapseudoniphargus Notenboom, 1988, Rhipidogammarus Stock, 1971, Sensonator, Notenboom, 1986; Metahadzia Stock, 1977).

The previous process of fusion of genera and families of Amphipoda together, present in the middle of last century, is replaced now with the actual global tendency in the taxonomy of amphipods towards the maximal splitting of various taxa into new genera, families and other high level categories, in addition to the discovery of many new taxa over the World. For this reason, the systematic of Amphipoda is very fluid now and needs one time-distance and new data to understand, recognize and accept numerous established new taxonomic high level categories.
Within the genus Niphargus, only a few taxa are mentioned from Spain [Niphargus ciliatus cismontanus Margalef, 1952, N. delamarei Ruffo, 1954, N. longicaudatus Costa, 1852], or mentioned Niphargus sp. (Margalef, 1963 [17], 1970 [18]; Ginet, 1977 [7]; Notenboom, 1988 [20], 1990 [21]). Recently Karaman, G. (2015, in press) [15], described two new taxa of this genus from Spain; Niphargus notenboomius, sp. $\mathrm{n}$. and $N$. laisi geronensis, ssp. $\mathrm{n}$.

During our present study of this fauna from Spain, we established in various localities in Spain the species Niphargus gallicus Schellenberg, 1935, and $N$. delamarei Ruffo, 1954, presented in this work. Probably, numerous other taxa of genus $\mathrm{Ni}$ phargus will be discovered in Spain in the future, and put more lights on the connection of subterranean Iberian fauna of Amphipoda with fauna of adjacent regions of Europe.

\section{MATERIAL AND METHODS}

The collected material was preserved in the $70 \%$ ethanol. The specimens were dissected using a 
WILD M20 microscope and drawn using camera lucida attachment. All appendages were temporarily submersed in the mixture of glycerine and water for study and drawing. Later, all appendages have been transferred to Liquid of Faure on permanent slides. The body-length of examined specimens were measured by tracing individual's mid-trunk lengths (from tip of head to end of telson) using camera lucida. All illustrations were inked manually. Some morphological terminology and setae formulae follow G. Karaman's terminology (Karaman, G., 1969 [8]; 1970 [9]; 2012 [14]) regarding the last mandibular palpus article $[\mathrm{A}=$ setae on outer face; $\mathrm{B}=$ setae on inner face; $\mathrm{C}=$ additional setae on outer face; $\mathrm{D}=$ lateral marginal setae; $\mathrm{E}=$ distal long setae] and propodus of gnathopods 1 and 2 [ $\mathrm{S}=$ corner spine; $\mathrm{L}=$ lateral slender serrate spines; $M=$ facial setae; $R=$ subcorner spine on inner face]. Terms "setae" and "spines" are used based on its shape, not origin.

All studies in this work are based on the classic morphological, ecological and zoogeographical studies.

\section{RESULTS AND DISCUSSION}

Family Niphargidae

Genus Niphargus Schiödte, 1849

\section{NIPHARGUS GALLICUS Schellenberg, 1935}

Figures 1-7

Niphargus fontanus Bate, Chevreux, 1901: 201; Figures. 1-2 [4];

Niphargus fontanus Bate, Chevreux \& Fage,

1925: 217, Figure 226 [5];

Niphargus gallicus, nom. nov., Schellenberg, 1935, 206 (key) [23];

Niphargus gallicus, Schellenberg, 1936: 4 [24]; Barnard \& Barnard, 1983: 691 [3]; G. Karaman \& Ruffo, 1986: 525 [12]; G. Karaman, Gledhill \& Holmes, 1994: 318 [13].

\section{MATERIAL EXAMINED: SPAIN:}

E7 $=86-8 / 27$, province Gerona, well (2): 250 $\mathrm{m} \mathrm{W}$ of the road La Bisbal d'Emporda-Ullastret, 1.5 $\mathrm{km} \mathrm{N}$ of the bifurcation with the road C $255(=20$ $\mathrm{km}$ E of Gerona), UTM coord. EG05, depth $5.5 \mathrm{~m}$, 13.8.1986, several exp. intermixed with Niphargus notenboomius G. Kar. (leg. J. Notenboom).

E-9 $=86-8 / 14$, province Barcelona, well $2 \mathrm{~km}$ $\mathrm{S}$ of Igualada, $30 \mathrm{~m}$ E of the road to Santa Margarida do Montbui, alt. $400 \mathrm{~m} \mathrm{ASL}$, (=about sea level), 10.8.1986, 2 ovig. females (leg. J. Notenboom), mixed with Haploginglymus sp, juv. and $N$. $c f$. notenboomius.
E-11= 86-8/36= province Gerona, well (2) just W of Sant Miguel de Fluvia $(=11 \mathrm{~km}$ SSE of Figueres), alt. $50 \mathrm{~m}$ ASL, 14.8.1986, 2 exp. males (leg. J. Notenboom).

E-13 = 86-8/31, province Gerona, well, SBR $\mathrm{Ru}$ Fluvia, near Orfes ( $=17 \mathrm{~km} \mathrm{SSW}$ of Figueres, alt. $50 \mathrm{~m}$ ASL, 13.8.1986, 1 female (leg. J. Notenboom). E-15 = 86-8/26, province Gerona, well $200 \mathrm{~m}$ $\mathrm{W}$ of the road La Bisbald Emporda-Ullastret, 1.5 $\mathrm{km} \mathrm{N}$. of the bifurcation with the road C $255(=20$ $\mathrm{km}$ E of Gerona), alt. $25 \mathrm{~m}$ ASL, 13.8.1986, 1 female (leg. J. Notenboom).

DESCRIPTION: FEMALE $5.0 \mathrm{~mm}$ with setose oostegites and eggs: Body relatively slender, mesosomal segments smooth; metasomal segments 1-3 with 2-5 dorsoposterior marginal short setae each (Figure 1I). Epimeral plates 1-3 quadrate, with well marked ventroposterior corner defined by strong spine-like seta and convex posterior margin bearing 3-4 setae (Figure 1I); ventral margin of epimeral plate 1 straight, that of epimeral plates $2-3$ convex and bearing 1 submarginal spine each.

Urosomal segment 1 on each dorsolateral side with 1 seta; urosomal segment 2 on each dorsolateral side with 1 spine, urosomal segment 3 naked (Figure $3 \mathrm{E})$. Urosomal segment 1 on each ventroposterior side with one short spine near basis of uropod 1 peduncle (Figure 3E).

Head with short rostrum and short subrounded lateral cephalic lobes and ventroanterior sinus (Figure $1 \mathrm{C}$ ), eyes absent.

Antenna 1 almost reaching half of body (ratio: 24:50), peduncular articles $1-3$ progressively shorter (ratio: 50:32:15), scarcely setose (Figure 1A), article 1 with 2 stronger spine-like setae, article 2 at dorsal margin with 1 plumose and 2-3 simple setae, at ventral margin with 2 pairs of simple short setae; article 3 almost naked (Figure 1A ). Main flagellum consisting of 19 articles scarcely setose (most of articles with 1 aesthetasc reaching or exceeding half of article-length). Accessory flagellum short, 2-articulated (Figure 1A).

Antenna 2: peduncular article 3 short, with 3 distal setae (Figure 1B). Peduncular articles 4 and 5 of equal length, bearing at ventral margin several bunches of setae (the longest setae are twice longer than diameter of articles themselves, along dorsal margin with several shorter setae each; peduncular article 4 at dorsal margin with one strong median spine (Figure 1B). Flagellum longer than last peduncular article and consisting of 10 articles bearing short marginal setae each (Figure 1B).

Mouthpart well developed. Labrum broader than long, with almost straight distal margin (Figure 
2A). Labium broader than long, with entire outer lobes and narrow inner lobes (Figure 1D).

Mandible with triturative molar. Left mandible: incisor with 5 teeth and lacinia mobilis with 4 teeth and 5-7 rakers. Right mandible incisor with 4 teeth (Figure 1G) and lacinia mobilis bifurcate, pluritoothed accompanied by $6-7$ rakers. Palpus mandibulae 3-articulated: first article short, naked; second article with 7 lateral setae (Figure 1E); article 3 subfalciform, slightly longer than article 2 (ratio: 68:50), with 12 marginal D-setae and distal 4 long E-setae; on outer face of article 3 appears one row of 5 A-setae (Figure 1E), on inner face appear 2 pairs of B-setae (Figure 1F).

Maxilla 1: inner plate with 1 seta, outer plate with 6 spines bearing 1 lateral tooth each (Figure $5 \mathrm{~A}$ ), inner spine with 3-5 very small teeth; palpus 2articulated, not reaching distal margin of outer plate spines and bearing 3 distal setae (Figure 5A).

Maxilla 2: inner lobe is shorter than outer one, both with marginal setae only (Figure 5B).

Maxilliped: inner plate short, with 2 distal pointed spines accompanied by single setae (Figure $1 \mathrm{H})$; outer plate reaching half of palpus article 2 , along inner margin with row of pointed spines; palpus article 3 at outer margin with distal bunch of setae only; palpus article 4 (dactylus) at outer margin with one median seta, at inner margin with 2 distal setae near basis of the nail (Figure 1H).

Coxae1-4 relatively shallow, bearing several marginal setae each. Coxa 1 broader than long (ratio: 50:35), poorly rhomboid but with obtuse ventroanterior corner (Figure 2B). Coxa 2 quadrate, nearly as long as broad (fig. 2E). Coxa 3 hardly broader than long, (ratio: 56:52) (Figure 3A). Coxa 4 broader than long (ratio: 58:50), without distinct ventroposterior lobe (Figure 2C).

Coxae 5-7 shallow, scarcely setose, progressively smaller towards coxa 7 . Coxa 5 broader than long (ratio: 66:36), with anterior subrounded lobe and narrowed posterior lobe (Figure 4A). Coxa 6 broader than long (ratio: 55:28) (Figure 4C). Coxa 7 entire, with convex ventral margin, broader than long (ratio: 50:25) (Figure 4E).

Gnathopods 1-2 relatively large, with propodus slightly larger than corresponding coxae. Gnathopod 1: article 2 short and strong, along anterior and posterior margin with several long setae (Figure 2B); article 3 at posterior margin with 1 median bunch of setae. Article 5 much shorter than article 6 (propodus) (ratio: 31:50), along anterior margin with distal bunch of long setae (Figure 2B). Propodus subtrapezoid, slightly longer than broad (ratio: 81:67), along posterior margin with 4 transverse groups of setae (Figure 2C).
Palm convex, inclined slightly over half of propodus-length, defined on outer face by one corner $\mathrm{S}$-spine accompanied laterally by 3 serrate L-spines and 3 facial M-setae (Figure 2C), on inner face by 1 subcorner R-spine (Figure 2D). Dactylus reaching posterior margin of propodus, along inner margin with 4-6 median setae, along outer margin with one median seta (Figure 2C).

Gnathopod 2 moderately larger than gnathopod 1 , article 2 along posterior margin with several long setae, along anterior margin with 4-5 short setae (Figure 2E); article 3 at posterior margin with one distal bunch of setae; article 5 shorter than article 6 (propodus) (ratio: 37:60), along anterior margin with 2 bunches of setae (Figure 2E). Propodus almost pyriform, longer than broad (ratio: 113:75), along posterior margin with 4 transverse groups of setae (Figure 2F). Palm convex, inclined almost 2/3 of propodus-length, defined on outer face by $1 \mathrm{~S}$ spine accompanied laterally by 1 serrate L-spine and 3 long facial M-setae (Figure 2F), along inner face by 1 short subcorner R-spine (Figure 2G). Dactylus exceeding posterior margin of propodus, along inner margin with 6 single setae, along outer margin with one median seta (Figure 2F).

Pereopods 3-4 moderately slender. Pereopod 3: article 2 along posterior margin with row of long setae, along anterior margin with 2 long proximal and 5-6 short distal setae (Figure 3A). Articles 4-6 of unequal length (ratio: 53:33:43); article 4 along both margins with several setae up to as long as diameter of article itself (Figure 3A); article 5 at anterior and posterior margin with 2 slender spines; article 6 at posterior margin with 4 short spines. Dactylus much shorter than article 6 (ratio: 17:43), at inner margin with one slender spine, at outer margin with one median plumose seta (Figure 3B); nail slightly shorter than pedestal (ratio: 27:32) (Figure 3B).

Pereopod 4: article 2 along posterior margin with several long setae, along anterior margin with 2 long proximal setae and 2-3 distal short setae (Figure 3C); articles 4-6 of unequal length (ratio: 48:30:43), scarcely setose; article 6 at posterior margin with 5 bunches of short spines. Dactylus much shorter than article 6 (ratio: 15:43), at inner margin with one slender spine near basis of the nail, along outer margin with one median plumose seta (Figure 3D); nail shorter than pedestal (ratio: 23:30).

Pereopods 5-7 progressively longer (Figure 4A, C, E). Pereopod 5: article 2 dilated, longer than broad (ratio: 70:43), along anterior margin with 4-5 spine-like setae, along posterior margin with 6 short setae (Figure 4A), ventroposterior lobe only marked, not fully developed. Articles 4-6 of unequal length (ratio: 50:41:62), articles along both margins with 
strong spines often longer than diameter of articles themselves (Figure 4A); article 6 slightly shorter than article 2 (ratio: 62:70), with 3 long distal setae. Dactylus much shorter than article 6 (ratio: 21:62), at inner margin with one strong spine, at outer margin with one median plumose seta (Figure 4B); nail much shorter than pedestal (ratio: 16:41).

Perpod 6: article 2 longer than broad (ratio: 79:47), along anterior poorly convex margin with 4 5 longer spine-like setae, along posterior almost straight margin with 5 short setae (Figure 4C), ventroposterior lobe not fully developed. Articles 4-6 of unequal length (ratio: 63:66:97), along both margins with bunches of strong spines, spines are longer towards distal part of pereopod. Article 6 is slightly longer than article 2 (ratio: 98: 79). Dactylus slender, much shorter than article 6 (ratio: 36:98), along inner margin with one strong spine, along outer margin with one median plumose seta (Figure 4D); nail much shorter than pedestal (ratio: 23:56).

Pereopod 7: article 2 much longer than broad (ratio: 85:48), along slightly convex anterior margin with 4 long spine-like setae, along posterior more convex margin with 7 short setae, ventroposterior lobe poorly marked (Figure 4E). Articles 3-6 relatively large regarding article 2 (Figure 4E, F); articles 4-6 of unequal length (ratio: 60:70:117), with strong spines at both margins, article 6 with 2 long distal setae. Article 2 is shorter than article 6 (ratio: 85:117). Dactylus slender, much shorter than article 6 (ratio: 28:117), along inner margin with one spine near basis of the nail, along outer margin with one median plumose seta (Figure 4G); nail much shorter than pedestal (ratio: 2372 ).

Pleopods 1-3 with 2 retinacula each. Peduncle of pleopod 1 with one distal strong seta (in lateral projection) (Figure 5C); peduncle of pleopod 2 along posterior margin with one median seta (Figure 5D); peduncle of pleopod 3 along posterior margin with 3 strong setae (Figure 5E).

Uropods 1-2 strong. Uropod 1: peduncle remarkably longer than rami, bearing dorsoexternal and dorsointernal row of strong spines (Figure 3E); outer and inner ramus of equal length, both rami with several lateral and distal strong spines; the longest distal spines exceeding half of rami-length (Figure 3E).

Uropod 2: peduncle with lateral spines (Figure $3 \mathrm{E}$ ); rami of nearly equal length, bearing strong lateral and distal spines; the longest distal spines exceeding the half of rami-length (Figure $3 \mathrm{E}$ ).

Uropod 3 strong and short (Figure $2 \mathrm{H}$ ). Peduncle slightly longer than broad, with distal spine and seta; inner ramus short, scale-like, with one short lateral simple seta and distal simple seta and spine. Outer ramus strong, along outer margin with 4 bunches of strong spines (the longest spines exceeding diameter of article itself) (Figure 2H), along inner margin 4 bunches of strong spines intermixed with single plumose seta as long as spines themselves. Second article of outer ramus much shorter than first article (ratio: $35: 122$ ), slightly longer than distal spines of first article and bearing 2 pairs of simple setae.

Telson longer than broad (ratio: 90:72), incised slightly over $2 / 3$ of telson-length; lobes slightly tapering distally, bearing 3 long distal spines [the longest spine slightly exceeding half of telsonlength (ratio: 47:90)]; one very long plumose seta is attached in upper lateral side, accompanied by one short plumose seta (Figure 5F).

Coxal gills relatively short, ovoid, on gnathopod 2 and pereopod 3 not reaching ventral tip of corresponding article 2 (Figures. 2E, 3A); coxal gill on pereopod 4 reaching ventral tip of article 2 (Figure $3 \mathrm{C})$. Coxal gill on pereopods 5 and 6 short, ovoid (Figure 4A, C).

Oostegites very large, ovoid, bearing marginal setae (Figures. 2E; 3A, C; 4A).

MALE $5.3 \mathrm{~mm}$ : Very similar to the female except uropod 3. Metasomal segments 1-3 with 3-4 dorsolateral posterior setae each (Figure 6F) Epimeral plates 1-3 quadrate, with well marked ventroposterior corner and convex posterior margin bearing 3-4 short setae each. Epimeral plate 1 with poorly concave ventral margin, epimeral plates 2 and 3 with slightly convex ventral margin bearing one subventral spine each (Figure 6F). Urosomal segment 1 on each dorsolateral side with 1 strong seta, urosomal segment 2 on each dorsolateral side with 1 spine and 1 seta, urosomal segment 3 naked. Urosomal segment 1 on each side with 1 ventroposterior spine near basis of uropod 1-peduncle.

Antenna 1 nearly reaching half of body, peduncular articles 1-3 progressively shorter, like these in female; main flagellum consisting of $17+$ articles (distal articles missing) (most of articles with one aesthetasc).

Flagellum of antenna 2 longer than last peduncular article and consisting of 10 articles.

Mouthparts: Mandible palpus article 2 with 6 setae, article 3 with 4 A-setae, 4 single B-setae, 12$13 \mathrm{D}$-setae and 4 distal E-setae.

Maxilla 1: inner plate with 1-2 setae (Figure $6 \mathrm{~A})$, outer plate with 6 spines bearing 1 lateral tooth each and 1 spine with 3-5 very small teeth (serrate), palpus with 3 setae.

Maxilliped: inner plate with 2-3 distal pointed spines, palpus article 4 at outer margin with one median seta, at inner margin with 2 distal setae near basis of the nail. 
Coxae 1-7 shallow. Coxa 1 much broader than long (high) (ratio: 55:35) with slightly subrounded ventroanterior corner and 7 marginal setae (Figure 6B); coxa 2 slightly broader than long (ratio: 60:55), with 5 ventral setae (Figure 6C); coxa 3 broader than long (ratio: 65:57), with 4 marginal setae only (Fig. 6D); coxa 4 much broader than long (ratio: 62:52), with 2-3 marginal setae and undistinct ventroposterior lobe (Figure 6E). Coxae 5-7 like these in female (Figure 5J).

Gnathopods 1-2 large. Gnathopod 1: articles $2-5$ like these in female. Propodus slightly trapezoid, longer than broad (ratio: 90:72), along posterior margin with 5 transverse rows of setae (Fig. 5G); palm slightly convex, inclined poorly over half of propodus-length, defined on outer face by 1 corner $\mathrm{S}$-spine accompanied laterally by 2 serrate L-spines and row of 3 facial $\mathrm{M}$-setae (Figure $5 \mathrm{H}$ ), on inner face by 1 strong R-spine. Dactylus exceeding posterior margin of propodus, along inner margin with row of 4-6 submarginal setae, along outer margin with one median seta (Figure $5 \mathrm{G}$ ).

Gnathopod 2: articles 2-5 like these in female. Propodus ovoid, slightly longer than broad (ratio: 105:85), at posterior margin with 5 transverse rows of setae (Figure 5I); palm convex, strongly inclined nearly $2 / 3$ of propodus-length, defined on outer face by 1 strong corner $\mathrm{S}$-spine accompanied laterally by $1 \mathrm{~L}$-spine and facial $3 \mathrm{M}$-setae (Figure 5I), on inner face by 1 subcorner R-spine. Dactylus much exceeding posterior margin of propodus, with several submarginal setae along inner margin and with one median seta at outer margin (Figure 5I).

Pereopods 3-7 like these of female, including its dactyli. Basipodit of pereopod 7 much longer than broad (ratio: 88:50), along anterior margin with 5 single spine-like setae; along posterior slightly convex margin with 7 short setae, ventroposterior lobe poorly developed (Figure 5J).

Pleopods 1-3 with 2 retinacula each. Peduncle of pleopod 1 with 1 anterodistal seta; peduncle of pleopod 2 naked; peduncle of pleopod 3 along posterior margin with 4 strong setae (Figure 6J).

Uropod 1: peduncle longer than rami, with dorsoexternal and dorsointernal row of strong spines (Figure 6G); outer ramus almost as long as inner ramus, with 2 lateral bunches of strong spines and 4 distal spines (the longest distal spine slightly exceeding half of ramus-length (ratio: 34:64). Inner ramus with 2 lateral and 3-4 distal strong spines (the longest distal spine slightly exceeding half of ramuslength (ratio: 39:73) (Figure 6J).

Uropod 2: peduncle poorly shorter than inner ramus (ratio: 50:53), with row of dorsoexternal strong spines (Figure 6H); outer ramus poorly shorter than inner one, bearing a row of lateral and 5 distal long spines (the longest distal spine remarkably exceeding half of ramus-length (ratio: $35: 42$ ) (Figure 6H). Inner ramus with row of 3 strong lateral spines and 5 distal strong spines; the longest distal spine remarkably exceeding half of ramus-length (ratio: 38:42).

Uropod 3: peduncle slightly longer than broad (ratio: 44:26), with 3 distal spines; inner ramus scale-like, shorter than peduncle, bearing 2 distal spines (Figure 6I). Outer ramus long: first article along outer margin with 4 bunches of strong spines, along inner margin with 4 bunches of spines mixed with single short plumose setae; second article remarkably more narrow than first article, with missing distal part (Figure 6I).

Telson longer than broad (ratio: 86:60), incised almost $2 / 3$ of telson-length; each lobe with 3 distal spines, along inner side of each lobe appear 12 spines (Figure 6K) in upper part of outer margin is attached one long and one short plumose seta.

Coxal gills relatively short, subrounded (Figure $6 \mathrm{C}, \mathrm{D}, \mathrm{E})$.

\section{VARIABILITY}

Male 11 mm 4.5 mm (E-11). Uropods 1-2 with relatively long spines on both rami (Figure 7A, B).

Uropod 3: first article of outer ramus with less number of spines than these in E-7, and these spines are slightly shorter (Figure 7C), second article of outer ramus poorly shorter than first article (ratio: 98:106).Telson with relatively short distal spines (Figure 7D).

Female $3.8 \mathrm{~mm}$ with setose oostegites (E13): Maxilla 1 inner plate with 2 setae. Basipodit of pereopod 7 narrowed, much longer than broad (ratio: 103: 58), along anterior margin with row of slender spines, along posterior margin with 6-7 short setae, ventroposterior lobe visible (Figure 7E).

Uropods 1-2 with moderately long spines on both rami (Figure 7F, G). Uropod 3: first article of outer ramus with slightly less number of spines than these in E-7, and these spines are rather shorter (Figure $7 \mathrm{H}$ ); second article of outer ramus elongated, slightly exceeding half of first article (ratio: 85:156) (Figure $7 \mathrm{H}$ ). Telson is longer than broad (ratio: 90:65), incised nearly $2 / 3$ of telson-length bearing relatively short distal spines (Figure 7 I). Other taxonomic characters agree with these of E-7 locality.

\section{REMARKS AND AFFINITY}

The size and length of uropod 3 in males and females of this species is variable: very variable 
number and length of spines on first article of outer ramus; the second article of outer ramus in males can be shorter to longer than the first article. The second article of uropod 3 outer ramus in females can be short (reaching $1 / 3$ of first article) to long (reaching $4 / 6$ of the first article).

Length of spines on uropods $1-2$ can be rather short (Figure 7A, B, F, G) to long (Figure 6G, H).

Telson with distal spines short (Figure 7D) to long (Figure 5F).

Evidently various local populations with some different characteristics appear in all known areals, but we had no enough material in hands to study more in detail geographical variety of populations of this species.

The specimens from Spain described and figured in this paper, are very similar to description and figures of $N$. gallicus from S. France and Romania (shape of body, gnathopods, pereopods 3-7, epimeral plates, uropod 3 in males, a pair of long plumose setae on telson lobes, etc.).

But, some of our specimens from Spain (localities E-7, E-15), differ from these described and figured of France and Romania by Chevreux [4], Schellenberg [23] and Dancau [6] by presence of very long all spines on uropods $1-2$, much more spiniferous outer ramus of uropod 3 in male and female, presence of spines at inner margin of telson-lobes in male, by low number of setae along posterior margin of pereopod 7 basipodit, short second article of uropod 3 in female (that in male is partially cutted).

Some specimens from Spain show all transitive characters regarding number and length of spines on telson and uropods 1-3, and length of the second article of uropod 3 outer ramus in males and females.

Because of relatively scarce description and figures existing in literature of $N$. gallicus, further comparison between specimens from Spain and other localities was not possible.

By this way, based on known characterstics of $N$. gallicus from literature, it was not possible to divide the specimens of Spain from these from France and Romania, and we consider the specimens from Spain as identic with Niphargus gallicus Schell. 1935, although we cannot exclude the possibility that the established differences appear because of scarce and indistinct existing description of $N$. gallicus, or represent a distinct different populations or taxa.

Taxonomical position of $N$. gallicus show some affinities to the Niphargus jovanovici Complex (gnathopods, pereopods, mouthparts, telson with long plumose setae) (S. Karaman, 1960) [16], although uropod 3 show elongated second article of uropod 3 .

\section{LOCALITIES CITED:}

Chevreux (1901) [4] mentioned and figured some specimens of this species from well in Cette in S. France under the name Niphargus fontanus Bate.

Chevreux \& Fage (1925) [5] briefly described and figured the specimens of genus Niphargus from Cette (France) under name Niphargus fontanus Bate, mentioning also localities Montpelier and Nice. Schellenberg (1935 [23], 1936 [24]) nominated these specimens as a new species, Niphargus gallicus, sp. n. (nomen novum).

Balazuc (1954) [1] cited this species from France: Gard (Garons, well in Mas de Rapetellet); Herault (Montpellier); Balaruc, ville Tricou, together with $N$. pachypus); Alpes Maritimes (Nice), mentioning also in Pyrenee Orientales (Aries sur Tech, Prats de Mollo, alluvion of Tech river).

Dancau (1963) [6] compared the specimens of well in Agigea and Tekirghiol (region of Dobrogea) and Baia de Fier (region d Oltenie, Romania) with $N$. gallicus for Montpelier (France) considering specimens from Romania identic with $N$. gallicus from France. Karaman \& Ruffo (1986) [12] cited this species from the known localities only.

LOC. TYP.: wells in Cette, France.

DISTRIBUTION. Known from S. France, Spain and Romania.

\section{NIPHARGUS DELAMAREI Ruffo, 1954}

Niphargus delamarei Ruffo, 1954: 677, Figure IV; Balazuc, 1957: 75 [22];

Niphargus delamarei Morand-Chevat, 1972: 27 [19]; G. Karaman, 1980: 3 [10]; G. Karaman, 1986:31, figs. I-V [11];

Niphargus sp. Ginet, 1977: 175 [7].

\section{MATERIAL EXAMINED: SPAIN:}

E-1, 86-8/40, province Gerona, well $150 \mathrm{~m} \mathrm{~S}$ of the road to Peralada, about $2 \mathrm{~km}$ from Garriguella (=12 km NE of Figueres), UTM coord.: EG08, alt. about $50 \mathrm{~m}$ ASL, 14.8. 1986, well, 10 exp. mixed with $N$. laisi geronensis G. Kar. (leg. J. Notenboom).

E-2, 86-8/30, province Gerona, SBR Riu Fluvia, near railway bridge SW OF Sant Miguel de Fluvia (=12 km SSE of Figueres), UTM coord. DG96, alt.50 m ASL, well, 13.8.1986, 2 exp. mixed with $N$. notenboomius $\mathrm{G}$. Kar. and $N$. laisi geronensis $\mathrm{G}$. Kar. (leg. J. Notenboom). 


\section{REMARKS}

Ruffo described this species (1954) [22] from several localities in southern France based on non adult males. G. Karaman later (1986) [11] described female of this species from Cova de La Mosquera Cave in Gerona province, Spain. Based on recent studies we established this species in two other localities in NE Spain.

The specimens from Spain in hands agree mainly with the known taxonomical characters of this species from France and Mosquera Cave.

The adult males $8.2 \mathrm{~mm}$. Metasomal segments 1-3 with 4-5 short dorsoposterior marginal setae each. Epimeral plate 3 distinctly angular. Urosomal segment 1 at each ventroposterior corner with one strong spine. Urosomal segment 1 on each dorsolateral side with one seta; urosomal segment 2 on each dorsolateral side with 1 spine; urosomal segment 3 naked.

Antenna 1 long, peduncular articles 1-3 progressively shorter, scarcely setose, article 3 short; main flagellum with 33 articles bearing 1 aesthetasc each. Accessory flagellum 2-articulated, slightly shorter than last peduncular article.

Antenna 2: flagellum longer than last peduncular article, consisting of 17 articles.

Mouthparts like these in female, palpus article 3 of mandible palpus is remarkably longer than second article. Gnathopods 1-2 with relatively short carpus. Propodus of gnathopod 1 is similar to that of gnathopod 2 but only slightly smaller, both propodits ovoid, with one median seta at outer margin of dactylus. Palmar spines and setae like these in females (see G. Karaman 1986: 33, Figures 2-6).

Dactylus of pereopods 3-4 strong, at inner margin with one spine near basis of the short nail. Dactylus of pereopods 5-7 is stronger, at inner margin with one median and one subdistal spine near basis of the nail, along outer margin with 1-2 median spines and one plumose seta; nail is short and strong. Basipodit of pereopods 5-7 is narrowed, with linear posterior margin and without distinct ventroposterior lobe. Pereopod 7 is with elongated articles.

Pleopods 1-3 with 2 retinacula each; peduncle of pleopod 2 along outer margin with 2 median short spines, peduncle of pleopod 3 along posterior margin with several setae.

Uropod 1 peduncle with dorsointernal and dorsoexternal row of strong spines, rami of equal length, bearing lateral and distal strong spines.

Uropod 2: inner ramus is slightly longer than outer one, both rami with lateral and distal strong spines. Uropod 3: peduncle short, with 1-2 distal spines; inner ramus short, scale-like, with one distal strong spine as long as ramus itself, accompanied by one plumose seta; outer ramus 2-articulated: first article slender, along outer margin with 3 bunches consisting of 1-2 spines each, accompanied by single plumose setae; along inner margin with 5 bunches of strong spines consisting of 2-3 spines each; spines are mainly longer than diameter of article itself. Second article of outer ramus poorly shorter than first article, along inner margin with row of 3 long lateral and 2 distal spines, along outer margin with 1 median spine, all spines are remarkably longer than diameter of the article itself.

Telson very short and much broader than long, distinctly gaping; each lobe with 3 distal and one outer marginal spine; a pair of moderately long plumose setae is attached near the middle of each lobe.

\section{VARIABILITY}

The males are very similar to females; the second article of uropod 3 outer ramus in females is poorly shorter than that in males, or almost of the same size. The shape of epimeral plates and armature of the urosomal segments is similar in females and males.

Based on the present scare knowledge of $\mathrm{Ni}$ phargus fauna in Iberian peninsula and only limited knowledge of French taxa of this genus, at the moment is not possible to establish the close relationships of $N$. delamare $i$ with other taxa of this genus despite the partial affinity with Niphargus jovanovici-Complex (subgenus Jovaniphargus S. Kar., 1960) [16] (gnathopods, pereopods, epimeral plates, etc.), although telson is without long plumose setae, and second article of uropod 3 outer ramus is elongated. It is necessary to wait for discovery of other new taxa of genus Niphargus in Spain and France to understand the relationships of this species with other species in adjacent regions.

LOCUS TYPICUS: Baillaurie, Banyuls-surMer, France.

\section{LOCALITIES CITED:}

Ruffo, 1954 [22]: FRANCE: Baillaurie, Banyuls-sur-Mer; Le Bouloui; Pont du Boulou; La Raillere, Amelie-Ies-Bains;

Balazuc, 1957 [2]: FRANCE: Pyrenees orientales: Le Boulou; Amelie-les-Bains, la Raillere; Banyuls, la Baillaurie;

G. Karaman, 1986 [11]: SPAIN: Mosquera cave (= Cova de la Mosquera), Beuda, Gerona prov.

Present work: SPAIN: Figueres region, Gerona region. 
Acknowledgement. I am thankful to the Prof. Dr. Jos Notenboom from Holland for the loan of material used in this study.

\section{REFERENCES}

[1] J. Balazuc, Les amphipodes troglobies et phreatobies de la faune Gallo-Rhénane, Arch. Zool. Expé.Gén., 91 (1954), pp. 153-193.

[2] J. Balazuc, Notes sur les Amphipodes souterraines. II. Additions a la faune gallo-rhenane, Note. Biospeolog., 12 (1957), 67-80.

[3] J. L. Barnard, C. M. Barnard, Freshwater amphipods of the World. I, Evolutionary patterns II, in: handbook and bibliography, Hayfield Associates, Mt. Vernon, Virginia, 1983, pp. XIX +849 pages.

[4] E. Chevreux, Amphipodes des eaux souterraines de France et d'Algerie, I-VI, Bull. Soc. Zool. Fr., (1901), pp. 168-222.

[5] E. Chevreux, L. Fage, Amphipodes, Faune Fr., 9 (1925), pp. 1-438.

[6] D. Dancau,. Niphargus gallicus Schell., amfipod subteran nou pentru fauna R.P.R., Comunicarile Acad. Rep. Pop. Romine., 13 (1963), pp. 123-129.

[7] R. Ginet,. Amphipodes troglobies d'Espagne, Crustaceana Suppl., 4 (1977), pp. 173-176.

[8] G. Karaman, XXVII Beitrag zur Kenntnis der Amphipoden. Arten der Genera Echinogammarus Stebb. und Chaetogammarus Mart. aus der jugoslawischer Adriaküste, Glasn. Republ. Zav. Zašt. Prir. i Prirod. Muz., 2(1969), pp. 59-84.

[9] G. Karaman, 1970. XXV. Beitrag zur Kenntnis der Amphipoden, Kritische Bemerkungen über Echinogammarus acarinatus (S. Kar., 1931) und Echinogammarus stocki n. sp. Polj. Šum, 16 (1970), pp. 45-66.

[10] G. Karaman, Revision of Niphargus jovanovicigroup (Fam. Gammaridae) (Contribution to the Knowledge of the Amphipoda 110), Polj. Šum., 26 (1980), pp. 3-22.

[11] G. Karaman, Discovery of Niphargus delamarei Ruffo 1954 in Spain, with first description of females (Gammaridea: Niphargidae) (Contribution to the Knowledge of the Amphipoda 154), Polj. Šum., 33 (1986), pp. 29-42.

[12] G. Karaman, S. Ruffo, Amphipoda: NiphargusGroup (Niphargidae sensu Bousfield, 1982), in: Botosaneanu, L. (Edit.): Stygofauna Mundi, A Faunistic, Distributional, and Ecological Synthesis of the World Fauna inhabiting Subterranean Warers (including the Marine Interstitial), Leiden, E. J. Brill/ Dr. W. Backhuys, (1986), pp. 514-534.

[13] G. Karaman, T. Gledhill, M. C. Holmes, A new subterranean amphipod (Crustacea: Gammaridea: Niphargidae) from southern Ireland, with comments on its taxonomic position and the validity of the genus Niphargellus Schellenberg, Zool. J. Linnean Soc., 112 (1994), pp. 309-320.

[14] G. Karaman, Further investigations of the subterranean genus Niphargus Schiödte, 1849 (fam. Niphargidae) in Serbia. (Contribution to the Knowledge of the Amphipoda 264), Agric. For., 58 (2012), pp. 45-64.

[15] G. Karaman, Two new members of the family Niphargidae (Gammaridea) from Spain (Contribution to the Knowledge of the Amphipoda 281), Biol. Serb., 2015 (in press).

[16] S. Karaman, Weitere Beiträge zur Kenntnis der Jugoslavischen Niphargiden, Glasn. Prir. Muz. Beograd, Ser. B., 15 (1960), pp. 1-19.

[17] R. Margalef, Un Supraniphargus interessante de Vizcaya (Amphipoda Gammaridae), Miscelanea Zool., 1(5) (1963), pp. 32-34.

[18] R. Margalef, Anfipodos recolectados en aguas subterraneas del Pais Vasco, Munibe (San Sebastian), Soc. Cienc. Nat. Aranzadi., 22 (1970), pp. 169-174.

[19] C. H. R. Morand-Chevat, Bilan actuel du genre $\mathrm{Ni}$ phargus en France et en Espagne, Actes I. Col. Int. Niphargus Verona 1967, Mus. Civ. Storia Natur. Verona., 5 (1972), pp. 25-31.

[20] J. Notenboom, Biogeographical observations on the genera of Iberian stygobiont Amphipoda, Crustaceana Suppl., 13 (1988), pp. 122-133.

[21] J. Notenboom, Introduction to Iberian groundwater amphipods, Limnetica., 6 (1990), pp. 165-176.

[22] S. Ruffo, Anfipodi di acque interstiziali raccolti dal Dr C. Delamare Deboutteville in Francia, Spagna e Algeria, (Studi sui crostacei anfipodi XXXIX), Vie et Milieu, 4 (1954), pp. 669-681.

[23] A. Schellenberg, Schlüssel der Amphipodengattung Niphargus mit Fundortangaben und mehreren neuen Formen, Zool. Anzeiger., 111 (1935), pp. 204-211.

[24] A. Schellenberg, Bemerkungen $\mathrm{zu}$ meinem Niphargus-Schlüssel und zur Verbreitung und Variabilität der Arten, nebst Beschreibung neuer Niphargus-Formen, Mitt. Zool. Mus. Berl., 22 (1936), pp. 1-30. 


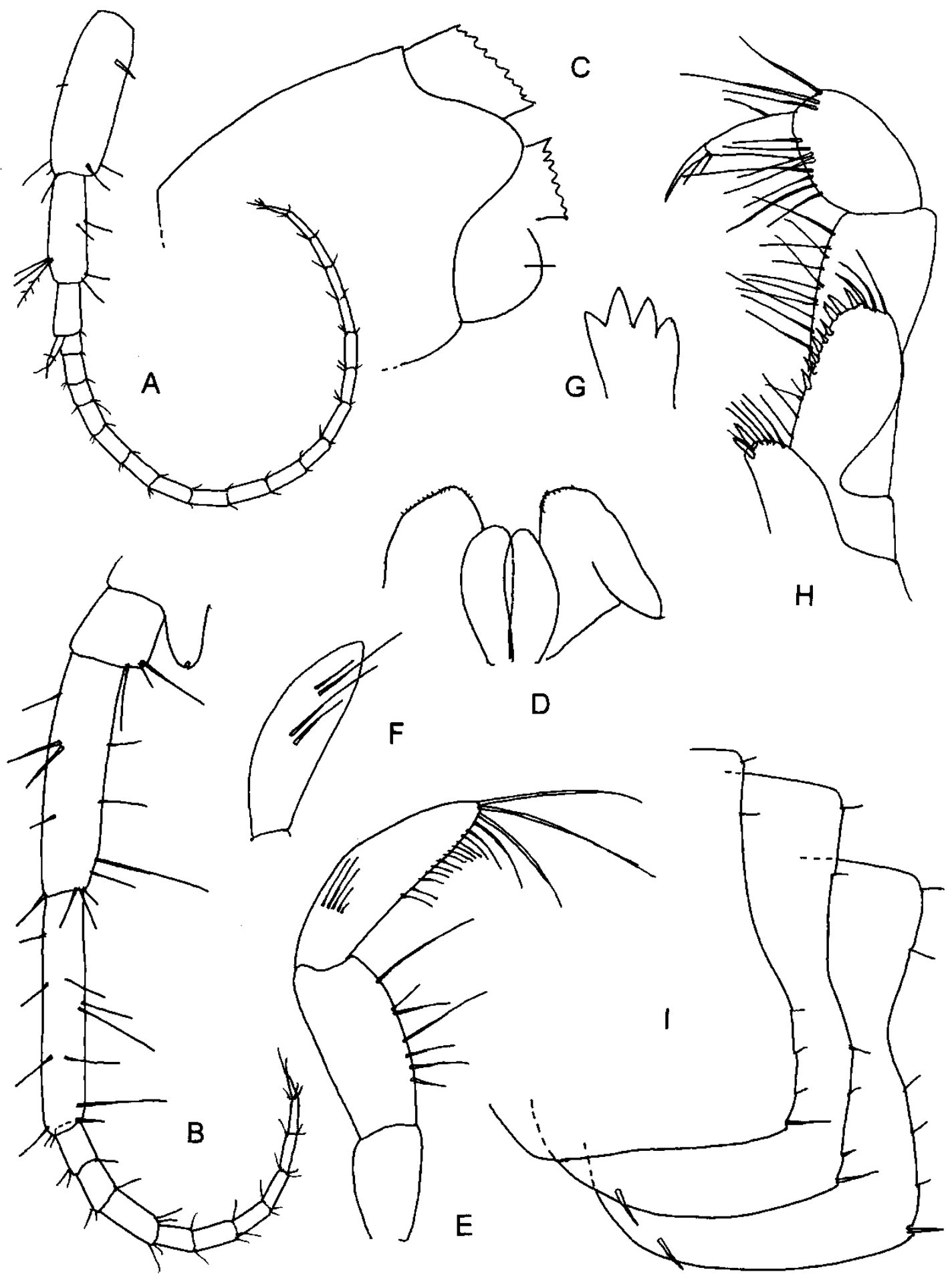

Figure 1. Niphargus gallicus Schellenberg, 1935, well near road La Bisbal d’ Emporda-Ullsstret, Gerona reg., female 5.0 mm: $\mathrm{A}=$ antenna $1 ; \mathrm{B}=$ antenna $2 ; \mathrm{C}=$ head $\mathrm{D}=$ labium; $\mathrm{E}=$ mandible palpus, outer face $\mathrm{F}=$ distal article of mandible palpus, inner face; $\mathrm{G}=$ right incisor; $\mathrm{H}=$ maxilliped; $\mathrm{I}=$ epimeral plates $1-3$. 

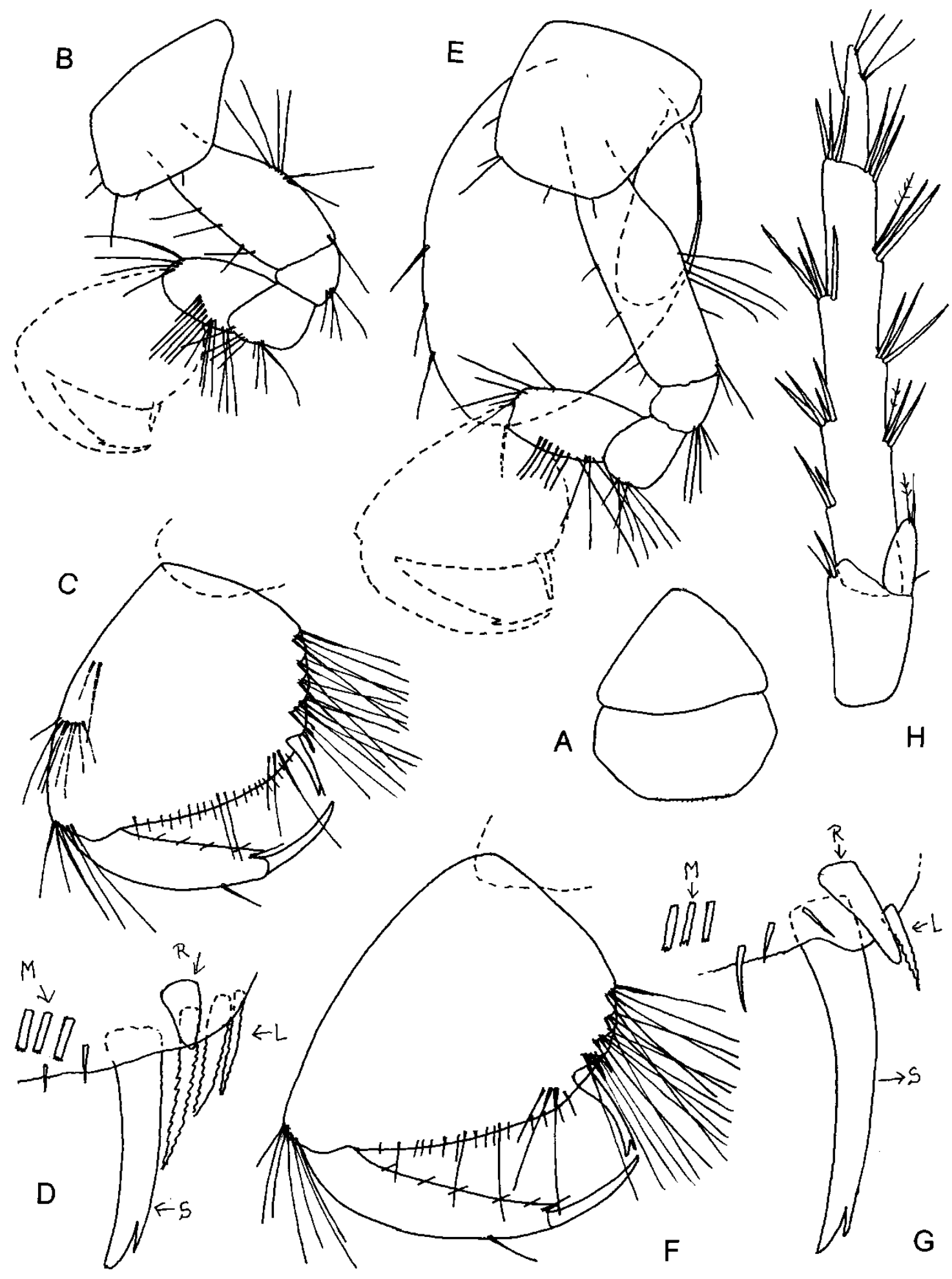

Figure 2. Niphargus gallicus Schellenberg, 1935, well near road La Bisbal d`Emporda-Ullsstret, Gerona reg., female $5.0 \mathrm{~mm}: \mathrm{A}=$ labrum; $\mathrm{B}-\mathrm{C}=$ gnathopod 1 , outer face; $\mathrm{D}=$ distal corner of gnathopod 1 propodus, inner face [S-corner spine; L-lateral spine; R-subcorner spine; $\mathrm{M}$-facial setae $; \mathrm{E}-\mathrm{F}$ = gnathopod 2, outer face; $\mathrm{G}=$ distal corner of gnathopod 2 propodus, inner face [ $\mathrm{S}$-corner spine; $\mathrm{L}$-lateral spine; $\mathrm{R}$-subcorner spine; $\mathrm{M}$-facial setae]; $\mathrm{H}=$ uropod 3. 


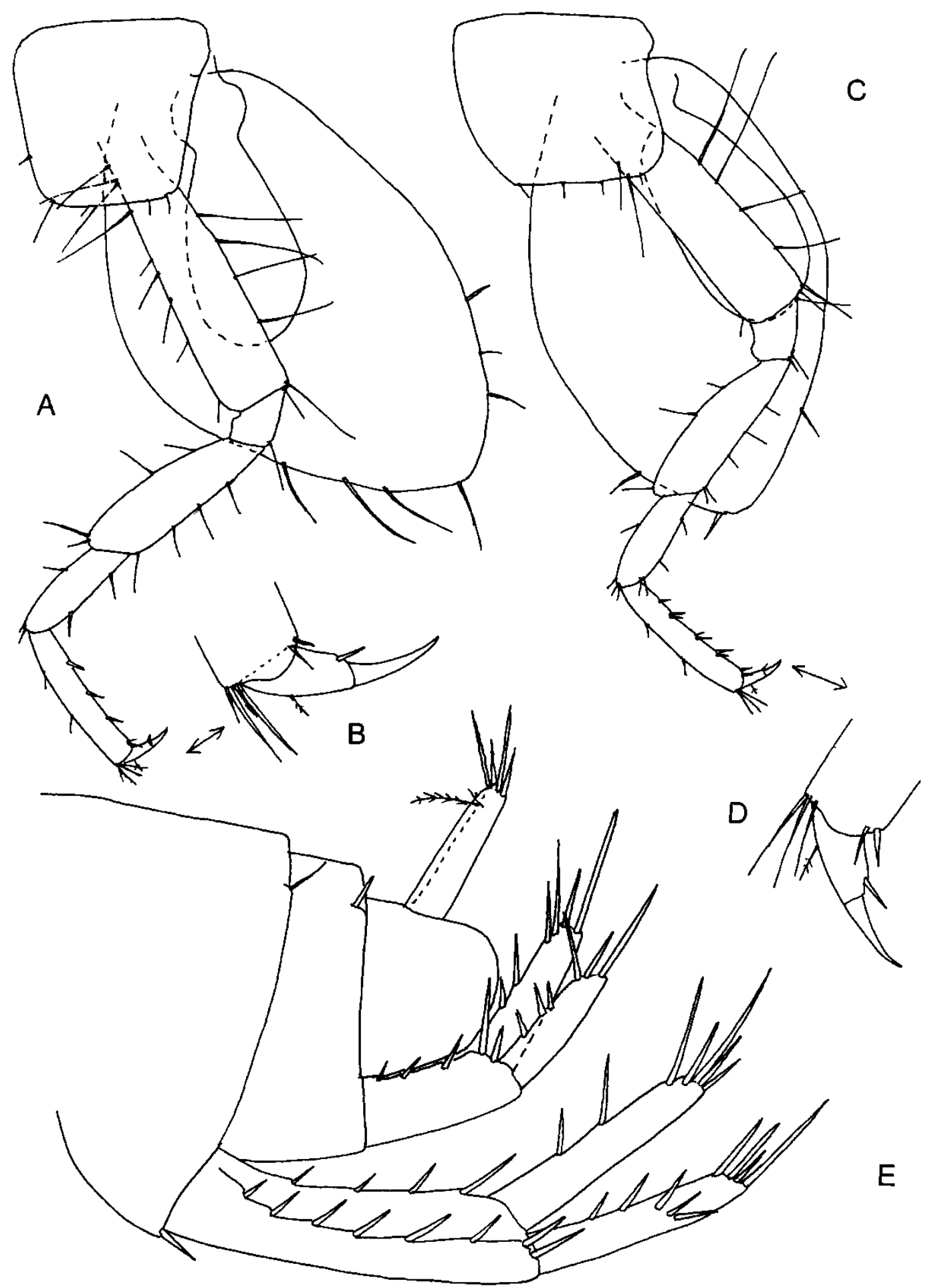

Figure 3. Niphargus gallicus Schellenberg, 1935, well near road La Bisbal d`Emporda-Ullsstret, Gerona reg., female $5.0 \mathrm{~mm}$. A-B = pereopod 3; C-D = pereopod 4; $\mathrm{E}=$ urosome with uropods $1-2$. 


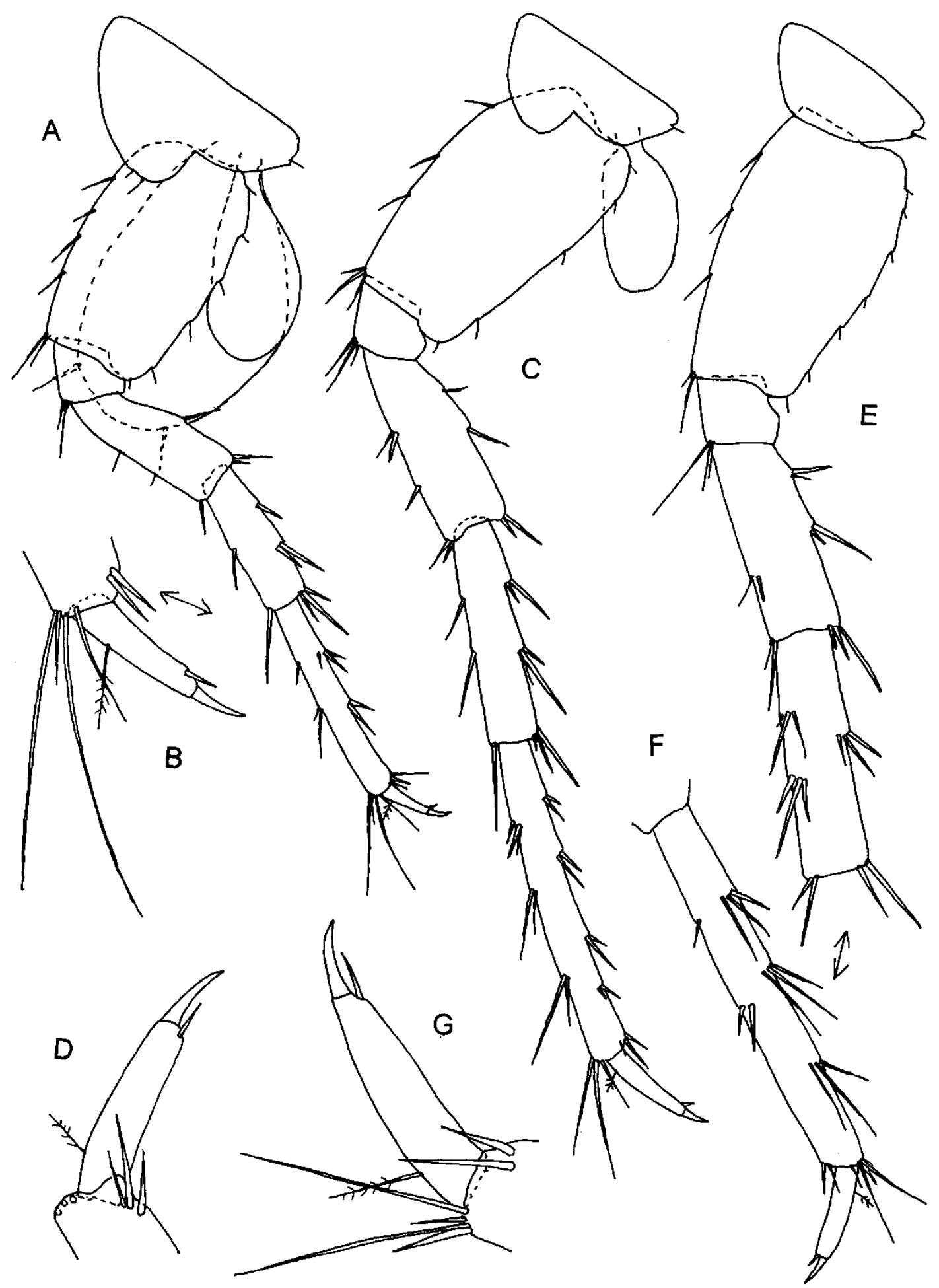

Figure 4. Niphargus gallicus Schellenberg, 1935, well near road La Bisbal d`Emporda-Ullsstret, Gerona reg., female $5.0 \mathrm{~mm}$. A-B = pereopod 5; C-D = pereopod 6; E-F-G = pereopod 7. 


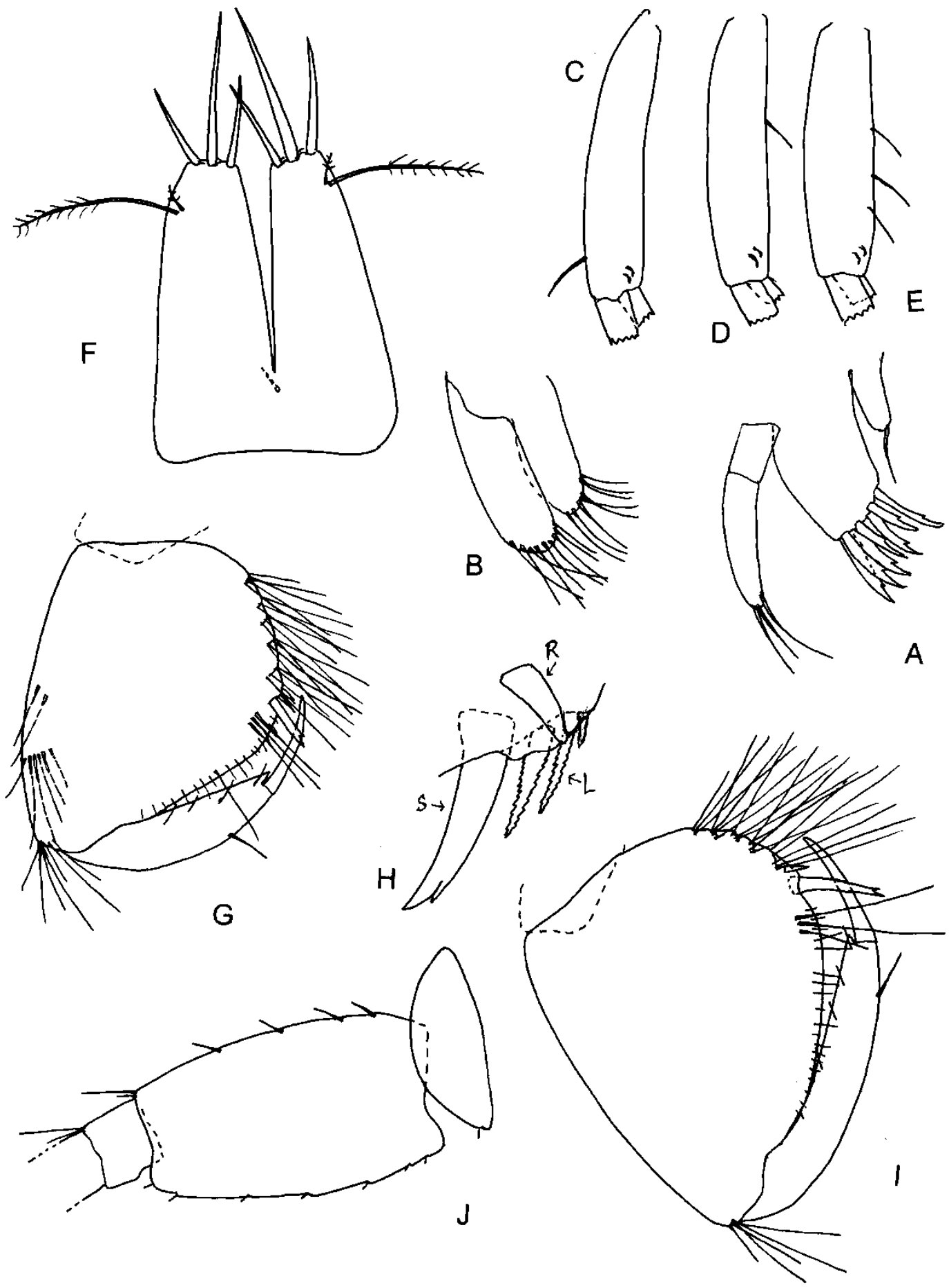

Figure 5. Niphargus gallicus Schellenberg, 1935, well near road La Bisbal d'Emporda-Ullsstret, Gerona reg. Female $5.0 \mathrm{~mm}$. A = maxilla $1 ; \mathrm{B}=$ maxilla $2 ; \mathrm{C}=$ peduncle of pleopod $1 ; \mathrm{D}=$ peduncle of pleopod 2 ; $\mathrm{E}=$ peduncle of pleopod $3 ; \mathrm{F}=$ telson.

Male $5.3 \mathrm{~mm} . \mathrm{G}=$ gnathopod 1 propodus, outer face; $\mathrm{H}=$ distal corner of gnathopod 1 propodus, inner face [S-corner spine; $\mathrm{L}$-lateral spine; $\mathrm{R}$-subcorner spine]; $\mathrm{I}=$ gnathopod 2 propodus; $\mathrm{J}=$ pereopod 7 basipodit. 


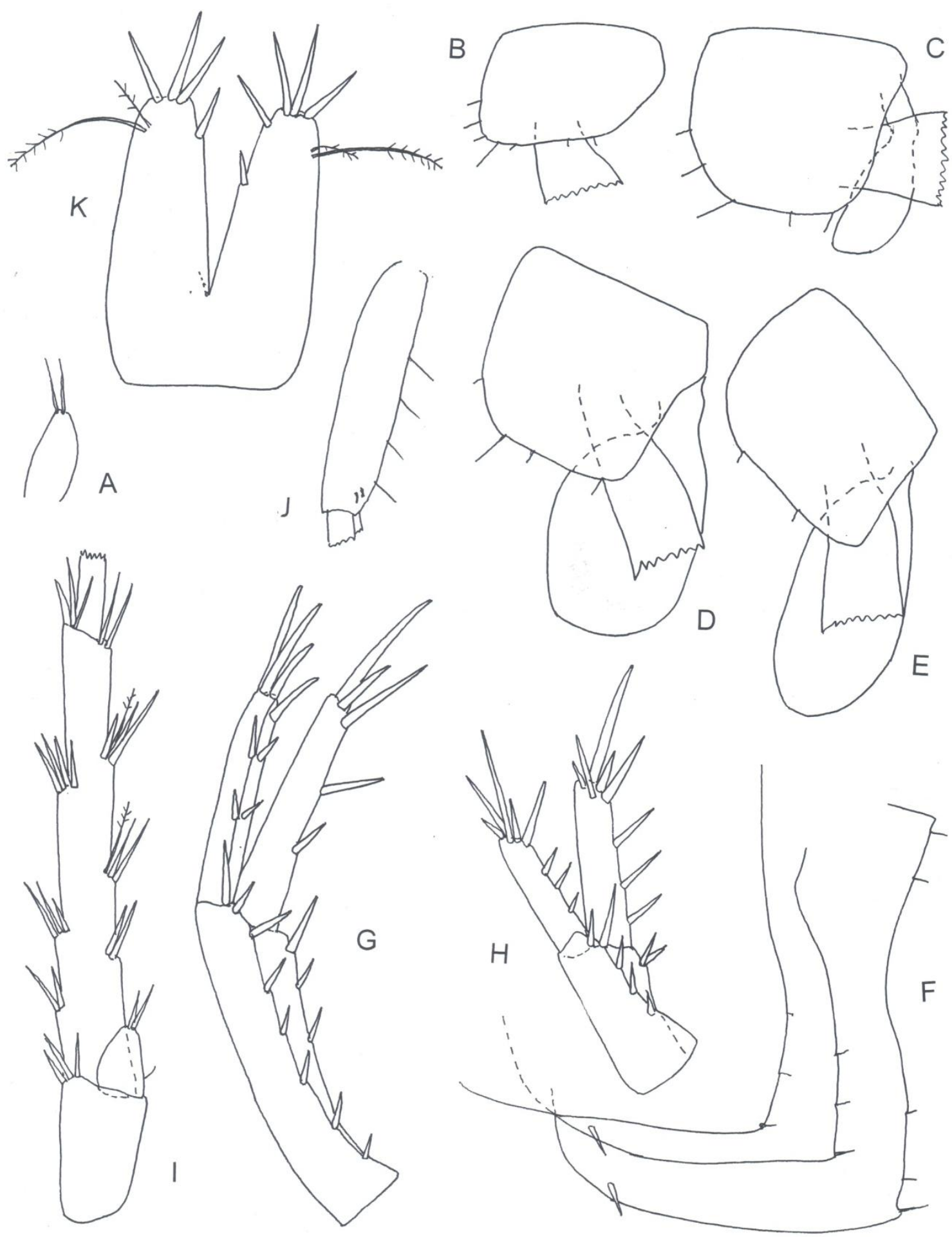

Figure 6. Niphargus gallicus Schellenberg, 1935, well near road La Bisbal d`Emporda-Ullsstret, Gerona reg., male $5.3 \mathrm{~mm}$. $\mathrm{A}=$ inner plate of maxilla $1 ; \mathrm{B}=\operatorname{coxa} 1 ; \mathrm{C}=\operatorname{coxa} 2 ; \mathrm{D}=\operatorname{coxa} 3 ; \mathrm{E}=\operatorname{coxa} 4 ; \mathrm{F}=$ epimeral plates $1-3 ; \mathrm{G}=$ $\operatorname{uropod} 1 ; \mathrm{H}=\operatorname{uropod} 2 ; \mathrm{I}=\operatorname{uropod} 3($ distal part missing); $\mathrm{J}=$ peduncle of pleopod 3. 


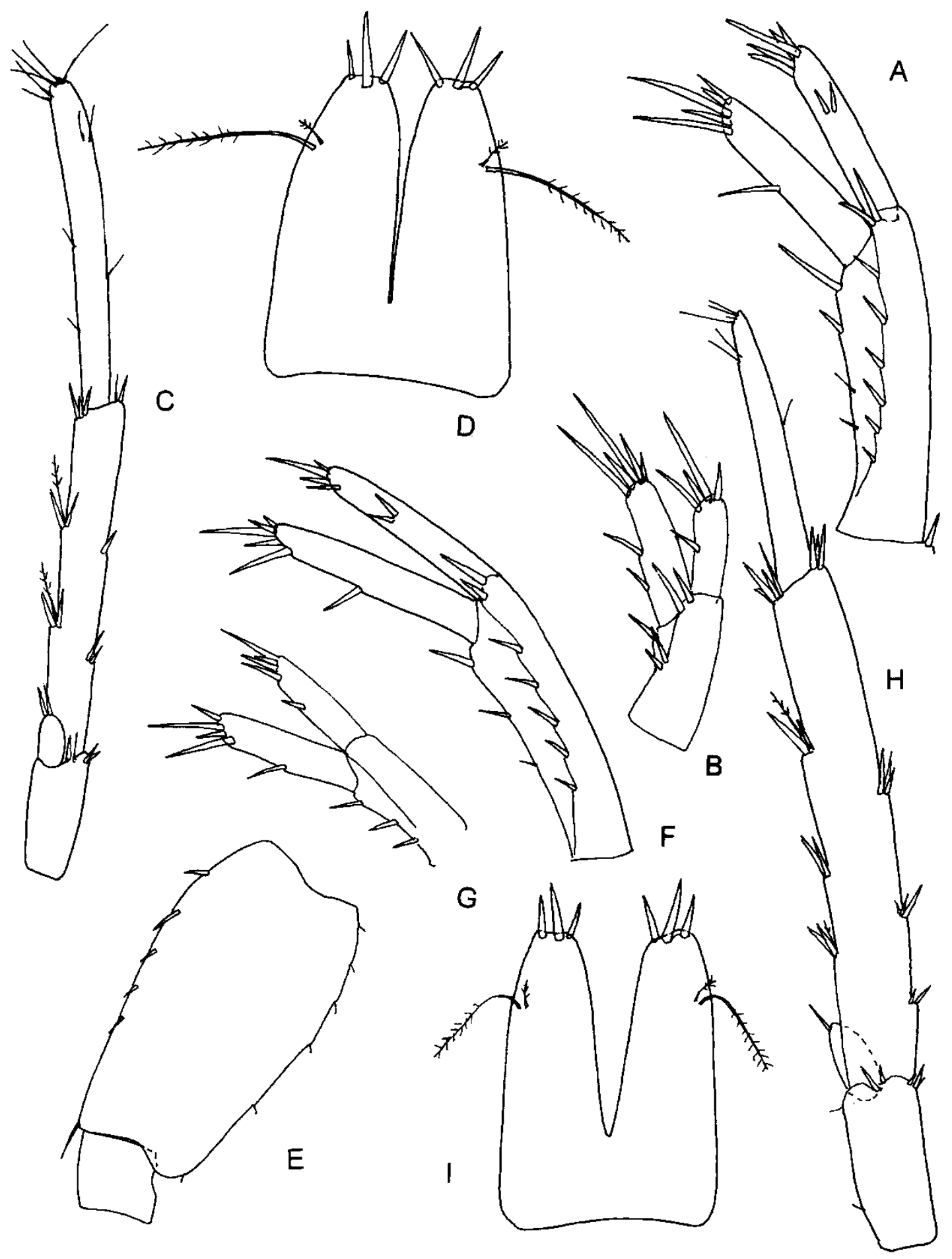

Figure 7. Niphargus gallicus Schellenberg, 1935: Well W of Sant Miguel de Fluvia, Gerona reg., male $4.5 \mathrm{~mm} . \mathrm{A}=\operatorname{uropod} 1 ; \mathrm{B}=\operatorname{uropod} 2 ; \mathrm{C}=\operatorname{uropod} 3 ; \mathrm{D}=$ telson.

Well in Ru Fluvia near Orfes, Gerona reg., female $3.8 \mathrm{~mm}$. E = pereopod 7 basipodit; $\mathrm{F}=$ uropod 1; $\mathrm{G}=\operatorname{uropod} 2 ; \mathrm{H}=\operatorname{uropod} 3 ; \mathrm{I}=$ telson. 


\title{
НОВИ ПОДАТОЦИ ЗА ДВА ПОДЗЕМНИ ВИДОВИ \\ ОД ФАМИЛИЈАТА NIPHАRGIDАЕ ОД ШПАНИЈА, \\ NIPHARGUS GALLICUS SCHELL., 1935 И N. DELAMAREI RUFFO, 1954 \\ (ПРИЛОГ КОН ЗНАЕЊЕТО ЗА АМРНІРОDА 282)
}

Гордан С. Караман

Црногорска академија на науките и уметностите, Подгорица, Црна Гора

\begin{abstract}
Се претставени нови податоци за две слабо познати подземни видови од семејството Niphargidae (Amphipoda Gammaridea) од Шпанија. Во подземните води, во североисточна Шпанија, е откриен и е опишан во детали видот Niphargus gallicus Schellenberg, 1935 година, познат во јужна Франција и во Романија. Се дискутира варијабилноста на видот N. gallicus во Шпанија, користејќи ги познатите таксономски карактеристики на овој вид од Франција и од Романија. Видот Niphargus delamarei Ruffo, 1954 година, кој беше познат во Франција и во еден локалитет во Шпанија, е откриен во бунарите на североисточна Шпанија, често измешан со други видови на Niphargus. Се дискутираат некои таксономски карактеристики и варијабилноста на овој вид.
\end{abstract}

Клучни зборови: таксономија; Amphipoda; Niphargidae; Niphargus gallicus; N. delamarei; Шпанија 